\title{
Linguocultural Anatomical Code: Concept of Sacredness
}

\author{
Moldir A. Alshynbaeva', Shara Mazhitayeva², Bektursyn Kaliyev³, Nurgul \\ Nygmetova ${ }^{4}$, Gulbaram S. Khamzina 5 \\ ${ }^{1}$ Graduate Student, Buketov Karaganda University, Kazakhstan. \\ E-mail:a_moon86@mail.ru \\ ${ }^{2}$ Doctor in Philology, Professor, Buketov Karaganda University, Kazakhstan. \\ Orcid: oooo-ooo2-0557-5423.E-mail: s_mazhit@mail.ru. \\ ${ }^{3}$ Candidate of Philology, Buketov Karaganda University, Kazakhstan. \\ E-mail: Kaliev-69@mail.ru \\ ${ }^{4}$ Candidate of Philology, Karaganda State Technical University, Kazakhstan. Orcid: oooo- \\ ooo2-6421-8231. E-mail: nurgul_tursynovna@mai.ru \\ 5PhD, M.Kozybaev North Kazakhstan State University, Kazakhstan. \\ Orcid: oooo-0oo2-7329-6258. E-mail: Gulzada_76@mail.ru
}

\begin{abstract}
The article examines the Kazakh people's linguocultural anatomical code, which has developed due to nomadic culture over the centuries and reflected their beliefs, rituals, rites, and traditions. The linguocultural code is viewed as a secondary modeling semiotic system, or as a connotative semiotics. Certain anatomical concepts, i.e. body parts, bones, and internal organs serve as the cultural code's elements. Culturally conditioned sacral significance, tracing to pagan magic, myths, and legends, is revealed in their lexical and phraseological representations in the connotative meaning. Thus, the article analyzes such concepts as 12 (on eki) múshe, jauyryn, ókpe. 12 (on eki) múshe serves as the basic concept of the Kazakh anatomical code, defining views on human and animals' anatomy, the role and functions of certain anatomical concepts in spiritual, religious, and ritual-rite culture. A high degree of sacredness of the named concepts, depending on the level of linguistic unit total number and cultural sacred meaning units, was identified as well. Thus, the purpose of our article is to identify the specifics of the Kazakh anatomical linguocultural code by analyzing certain sacred concepts, verbalized in the names of skeleton, bones, some inner organs, as well as to define the degree of their sacredness, preserved in the modern Kazakh language. We have developed the methodology for studying these concepts, based on the secondary semiotic sign analysis, i.e. lexical and phraseological verbal units and their semantics: denotative and connotative, and defined certain concepts' sacredness degree.
\end{abstract}

Keywords: concept sacredness, a symbolic animal, anatomical linguocultural code

\section{Introduction}

In semiotics, culture is viewed as a sign and symbol system. Ernst Cassirer in his philosophy of culture characterizes a person as a symbolic animal (animal simbolicum) that creates symbols and various cultural sectors (language, myths, religion, art, science) as special symbolic forms or systems (Cassirer 1998).

(C) AesthetixMS 2021. This Open Access article is published under a Creative Commons Attribution Non-Commercial 4.0 International License (http://creativecommons.org/licenses/by-nc/4.o/), which permits non-commercial re-use, distribution, and reproduction in any medium, provided the original work is properly cited. For citation use the DOI. For commercial re-use, please contact editor@rupkatha.com. 
Yu. M. Lotman mentioned culture as semiosphere, thereby emphasizing its globality. He interpreted the most important social culture as the human non-genetic memory, which keeps and transfers vast experience (see: Lotman 2000). He introduced the cultural code concept as an element of semiotic concept of culture. A certain cultural text can be considered both as a single code text, and as a set of codes texts. Moreover, each type of culture will be a dramatically complex code hierarchy. A speech-level cultural text is a combination of various systems, rather than a certain code embodiment. If two compatible code hierarchies are connected during the cultural contacts, then the result is a new cultural type. If, in contrast, two incompatible codes collide, then their mutual failure occurs: culture loses its language (see: Lotman 1996). Thus, a code is either a system of images related to a cultural area, or it is cultural artifacts serving as a sign function. From semiotic viewpoint, culture is a complex sign system. "An extensive image paradigm serving as a sign function in the communication process is one of its subsystems" (Lotman 1992, p. 117). Umberto Eco describes the code as "a system of communicative conventions, paradigmatically connecting elements, as well as a series of signs with a series of semantic blocks (or meanings) and setting the structure of both systems: each of them is followed by combinatorial analysis determining the order where the elements (signs and semantic blocks) are built syntagmatically" (Eco 1998, p. 27).

Based on the ideas of E. Cassirer and Yu. M. Lotman, the semiotic approach has become widespread in modern humanities, particularly in the study of various cultural codes by anthropologists, cultural scientists, sociologists, linguists, and literary scholars (see, e.g. Bukina 2008; Agapova 2009; Stepanova 2012; Akopyan 2015; Temirgazina 2016; Babosov 2016, etc.). Examining culture as a semiotic phenomenon, V.M.Savitsky notes: "One of the subsystems included in it is an extensive paradigm of images having the function of a sign in communication. It includes images drawn from business practices, rituals, games, common knowledge, beliefs, folklore, mythology, religion, literature, etc. The image signs extracted from cultural texts may separate from them and cause the creation of new cultural texts" (Savitsky 1996, p. 94). The above mentioned image paradigms in a sign-oriented form have a variable substance of expression. This means that they are embodied in different types of materials (pictural, sculptural, architectural, musical, verbal, etc.). Hence, codes permeate the entire culture. Their interaction is the information "rendering" from one code to another and, as a consequence, the transformation and creation of new information.

The study of the "cultural code" concept went further through the interaction between culture and language as two different semiotic systems, resulting in the "linguocultural code" multidisciplinary term (Dukalskaya 2011, p. 128). Since every native speaker is also a culture-bearer, linguistic signs may function as cultural signs and thereby serve as a means of representing the main cultural attitudes. Culture and language are analyzed in a single category system, namely the categories of semiotics. Cultural and verbal language codes are distinguished on this basis; they interact with each other, thereby resulting in hybrid-linguocultural codes, according to V.G. Akopyan (2015, p. 71).

Cultural codes, expressed in words, arise in fiction, as well as oral folk art and partially penetrate natural language, fixing there as image vocabulary, paremias, phraseological units, winged expressions, etc. Therefore, natural language units, connecting with image-culture codes, form linguocultural codes. In fact, any external reality, having a specific sensory imagery, can serve as a cognitive basis for creating a cultural code. A necessary condition for this is the familiarity of mother-tongue speakers with this area. For example, office workers must wear white shirts to work. This served as a figurative basis for creating such an English expression as a white collar worker. Culture-bound terms can be evaluated as "useful or harmful, dangerous or safe, pleasant or 
unpleasant, beautiful or ugly, etc. - with many gradations between the poles of evaluative scales" (Lotman 1992, p. 118).

Any complex of sensually perceived realities may serve as the cultural code foundation (flora, fauna, natural phenomena, weapons, tools, domestic and farm utensils, clothing, food products, buildings and other artifacts), as well as cultural scenarios, (workflows, festivals, games, competitions, battles, shows, auctions and other social and cultural transactions). In particular, the definition and classification of cultural codes proposed by V. V. Krasnykh are of interest, who defines cultural code as "a net which culture covers the surrounding world with, dividing, categorizing, structuring, and evaluating it" (Krasnykh 2002, p.103). The researcher identifies such types of cultural codes as: somatic, spatial, temporal, objective, biomorphic, spiritual, etc. that correlate with the ethnocultural archetypes and where a naive outlook on the universe is taken on.

The somatic code is characterized as one of the basic cultural codes along with spatial, temporal, objective, biomorphic and spiritual (Krasnykh 2002, p. 233). In addition, according to researchers, it has a special place among the basic codes as "the most ancient of the existing", since its formation origins are associated with the mythological thinking foundations, i.e. "a person began learning the world around him from knowing himself" (Krasnykh 2002, p. 233). D. B. Gudkov and M. L. Kovshova mention the cultural code as somatic, related to a human body and define it as "a set of names and/or their combinations, designating the whole body or its parts and specific to them qualitative (including "size", "color"/"suit", "shape", "consistency") as well as quantitative (including "size", "weight") characteristics, physical and/or mental, intellectual, emotional, etc. states or actions, postures, gestures and types of activity. It also includes their spatial and temporal "dimensions", which, in addition to their natural properties, bring meanings functionally significant for culture and give the role of cultural "language" signs to these names, e.g. "tooth and nail, by the sweat on one's brow, before one's eyes, keep smth.in one's head, without a second thought, turn a deaf ear to, after one's own heart, to the bone" (Gudkov, Kovshova 2007, p. 99).

The somatic code cultural content and its features in various languages has been studied in many works (Andersen 1978; Bodily code in Slavic cultures 2005; Enfield, Majid et al. 2006; Gudkov, Kovshova 2007; Dmitriuk 2009; Oinotkinova 2011; Kraska-Szlenk 2011, etc.). The scientists attach great attention to the comparative study of somatic code and certain names of body parts in two or more languages, aimed to identify the somatisms' general and specific features as code units and their functioning principles in different national cultures as well to describe the verbal somatic code's internal hierarchical structure, including both culture-universal and cultural and linguistic components (Liston 1972; Xin-i Guo 2005; Zavalishina 2005; Terrill 2006; Bashkatova 2014; Savchenko 2014; Temirgazina, Khamitova et al. 2016, etc.).

We propose to introduce the term "anatomical cultural code" into scientific use, which can be considered as a part of the somatic code. The anatomical cultural code includes metaphoric and symbolic ideas, views, myths, ritual practices that are ontologically related to the human body's inner structure, i.e. his organs, skeletal parts (liver, heart, kidneys, lungs, stomach, pelvis, skull, sacrum, etc.). In other words, the anatomical code does not include the names of body parts such as head, arm, leg, neck, palm, foot, shoulders, etc., which have been studied in detail in many linguistic cultures. "Anatomical vocabulary is included in the oldest and most stable layer of the national language" (Temirgazina, Akosheva et.al. 2019, p.150). The anatomical linguocultural code has not been studied enough. There are only a few works by Z.K. Temirgazina, M.K. Akosheva, K. Kh.Rakhimzhanov, etc. (Temirgazina, Akosheva et al. 2019; Temirgazina, Nikolaenko et al. 2020; Rakhimzhanov, Akosheva et al. 2020) based on the Kazakh language material against English, 
Russian, etc., in which certain concepts of the Kazakh anatomical cultural code have been examined.

V.M. Savitsky points to the linguocultural code's specific features semiotically, which is significant for our research: “... A great number of signs, having literal meanings, form primary (denotative) semiotics. However, above the two mentioned layers, there is sometimes the third one. There are signs for which the signs of denotative semiotics serve as a plane of expression. Taken together, they make up secondary (connotative) semiotics, i.e. a sign system built above the primary (denotative) one" (Savitsky 2016, p. 55). Presuming that the denotative semiotics signs in connotative semiotics serve as a building material for secondary signs, R. Bart (1994) called them as parasitic codes whereas the Tartu-Moscow school representatives as secondary modeling systems. According to what has been said, the anatomical linguocultural code can be considered as connotative semiotics.

\section{Material and methods}

The linguocultural code model as connotative semiotics with its some components, i.e. concepts, taking into account their formal and denotative representation, built as a methodological basis for further analysis in our article, can be presented in the following table:

Table 1. The linguocultural code model as connotative semiotics

Semiotic Code specificity
level

\begin{tabular}{|c|c|c|c|}
\hline \multirow{5}{*}{ 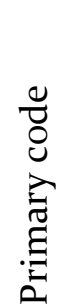 } & Cultural code unit & Artifact & Images, ideas \\
\hline & & Natural fact & \\
\hline & & Ritual & \\
\hline & & Custom & \\
\hline & & Rite, etc. & \\
\hline
\end{tabular}

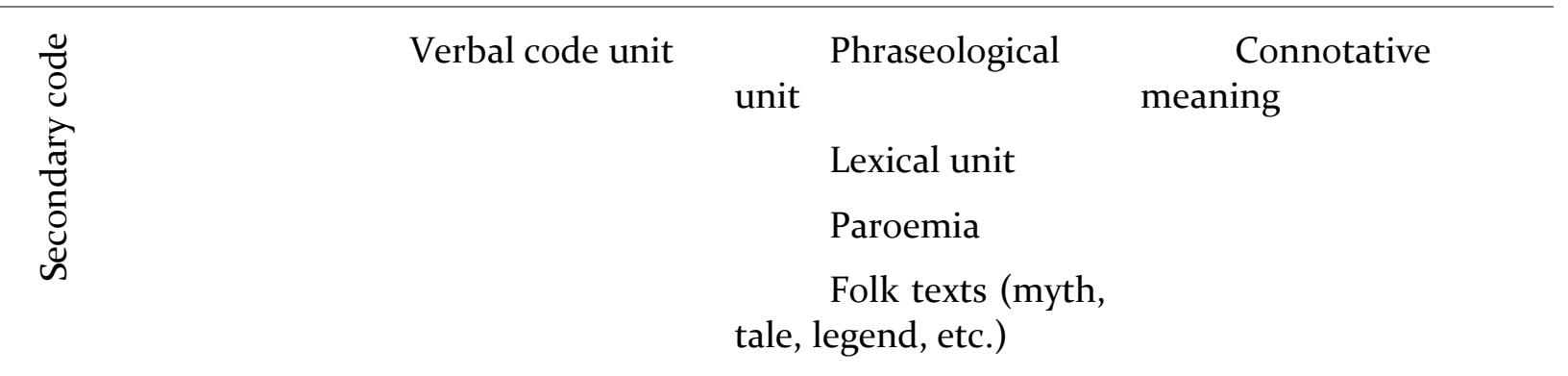

The linguocultural code model proposed by us allows developing methods for its study through linguistic units that verbalize anatomical concepts. The emphasis is laid on the analysis of anatomical names and phraseological units semantics including this name as a component. We reveal the denotative and connotative meanings and define connotation's cultural and sacred significance. "Names, belonging to a certain cultural code, have a special meaning as secondary 
semiotic system signs, in addition to general-linguistic. In addition, this meaning is by no means situation-dependent, but is attached to a particular linguistic unit" (Gudkov 2004, p. 42). Culturally conditioned content of the language's lexical units has been analyzed on the basis of phraseological units in detail. D. B. Gudkov and M. L. Kovshova explain the importance of phraseological units as an empiric material for studying the linguocultural codes by the fact that a phraseological sign has a special function of serving as a "language and culture" sign (Gudkov, Kovshova 2007, p.p. 87-88).

Having defined the linguocultural anatomical code's formality and its certain units, i.e. signs, we can outline the research material, which is represented by various verbal units: lexemes, the Kazakh language idioms, containing culture-significant information, and dating back to the ancient Kazakh culture codes. These units are the anatomical names of human structure: bones, inner organs, and body parts. The idioms, including these names, have been analyzed as well. Some lexical and phraseological units have denotative meaning, while the others have the same but complicated by various cultural and evaluative connotations. Some anatomical units still preserve sacred cultural meanings, due to the connection with the mythological code, rites, rituals, and dating back to the ancient Turkic pagan religious viewpoints. The semantic link between a linguistic unit and sacred concepts allows to define the degree of sacredness of a particular concept, preserved in the associative and semantic relationship of the two largest semiotic systems, i.e. culture and language.

The anatomical concept's sacredness will be estimated in accordance with the total number of one-root lexemes and idioms in their composition, as well as the number of linguistic units having sacred associative meanings. The degree of the anatomical concept sacredness under consideration will be presented in the table below. Anatomical names and phraseological units in their composition are selected from definition dictionaries and phrase books of the Kazakh language: I. K. Keńesbayev "Qazaq tiliniń frazeologılalyq sózdigi” (2007), Kh. K. Kozhakhmetova., R. E. Zhaisakova, Sh. O. Kozhakhmetova "Kazakh-Russian phrase book" (1988), K.B. Bektayev "Úlken qazaqsha-oryssha, oryssha-qazaqsha sózdik" (The Great Kazakh-Russian, Russian-Kazakh dictionary)" (1995); including electronic dictionaries (https://sozdik.kz).

\section{Results and Discussion}

\section{1. on eki múshe as the basic concept of the Kazakh anatomical code}

The anatomical code of the Kazakh people, being one of the largest modern Turkic peoples, has reflected the peculiarities of anatomical representations due to the people's specific mindset, nomadic culture, as well as historical and spiritual development. The linguistic unit semantics, i.e. words, idioms, has preserved pagan and mythological representations of the ancient Turkic nomads, their traditions, rites and rituals. Using both semantic and etymological analysis of these units, we will try to restore the anatomical representations of the ancient Kazakhs and to reveal their ethnocultural specifics. The names of human body parts, bones, and inner organs are included in the basic vocabulary and form many fixed phraseological expressions. The idioms with an anatomical name component reflect "the extant archaic concepts as relics of the Kazakh people's distant past. However, "archaic" phraseological units in their origin, due to their semantics, i.e. abstraction, movability, etc., function actively in the language, expressing quite modern and comprehensible concepts" (Kozhakhmetova, Zhaisakova, etc., 5).

The pagan and mythological views had a great influence on the formation of the Kazakhs' anatomical cultural code. According to the Proto-Kazakhs' ancient Tengreanian views, time in general and human life were cyclical (not linear, like among Europeans) and were determined by 
the twelve years and twelve months a year cycles. This ancient calendar is already several thousand years old. In addition to the motion of the Sun, Moon, and Earth, it takes into account the motion of Jupiter and Saturn as well. Jupiter is a giant planet that makes one revolution around the Sun in 12 years. It strongly affects the Earth's climate, causing it to change depending on the ratio with the Sun and the Earth, and every 12 years these changes occur, but with variations. Time and human life also develop as a spiral, where each circle includes twelve years, i.e. mýshel jas. Mýshel means "anniversary" (the ancient calculation of a person's age according to a twelve-year cycle) (Bektayev 1995, 337). The person's age depended not on the number of years lived, but on the number of mýshel (in the meaning of "a twelve year cycle") that he experienced. Therefore, a certain birthday was not significant for a Kazakh person, but the transition from one twelfth anniversary to another as follows: $13,25,37,49,61$.

The sacred significance of the transition from one mushel to another was traditionally celebrated by the Kazakhs by holding a big celebration called músheltol. The year of moving to a next mushel was especially important for a person as he had to follow a number of protective and magical actions for a safe transition into the next twelfth anniversary. He has to take care of himself and does not act impulsively, since it was this period when he became more vulnerable to evil spirits.

Thus, the number on eki (lit. "twelve") was sacred for the Kazakhs who lived in harmony with the surrounding nature and its laws. The human anatomy was also identified by this number, i.e. on eki múshe, which literally meant "twelve body parts". This included: a head, a spine, two shoulder blades, two hip bones, two shin bones, two humerus bones, two ulna bones. On eki múshe is the basic concept of the Kazakh anatomical code, which determines views toward humans and animals' structure, as well as the role and functions of individual anatomical concepts in spiritual, religious, ritual and ceremonial culture.

In the Kazakh culture, the sacredness of the number on eki is reflected in the language, where many phraseological units, having the number "twelve", function. The health and beauty of a person's constitution and his physical strength were metaphorically determined by the Kazakhs in accordance with the ratio and proportions of the above-mentioned twelve body parts. Hence, idioms arose in the Kazakh language: on eki múshesi teń (lit. "twelve body parts are the same/identical") in the meanings: 1) "He is well built"; 2) "He is slender and strong".

The metonymic mechanism, based on "PARTS OF THE BODY INSTEAD OF THE WHOLE BODY” analogy, defined a person's health in accordance with the state of twelve body parts, see the idiomatic expression: on eki múshem saý bolsa (lit. "If twelve body parts are healthy") in the meaning of "If I'm fine".

See other twelve component idioms, for example:

on eki dene mýshesi - lit. "twelve body parts";

on ekide bir gýli ashylmaǵan - lit. "out of twelve buds, no one has yet burst" in the meaning of "as young as button" (about a twelve-year virgin);

on ekide bir nuskasy joq - lit. "there is no one out of twelve parts of the whole" in the meaning of "nothing has yet begun; undone by anyone" (Kozhakhmetova, Zhaisakova, etc., p. 143).

The semantic and word formative connection of mushe and mushel words seems to be obvious and confirms their relationship in the pagan ideas of the ancient Kazakhs. Múshe has such a dictionary meaning as "a part of the body; organ; body region; organism" (Bektayev 1995, p.337). The verb with an "anatomical" meaning músheleý was formed from it, i.e. "to cut; to butcher; to 
dress; cutting; butchering; dressing" (Bektayev 1995, p.337). Kazakh people mastered specific skills in dressing carcasses (a sheep, a horse, etc.) into separate parts, i.e. múshe, by using a knife, not an ax. The invited master hand, i.e. qasapshy, slaughters an animal and dresses a carcass. He dresses the carcass into parts, i.e. múshe, each of which will later be served to guests in accordance with their age and status. Qasapshy is given a piece of meat for his work, which is called "qolkeser". He must be given the first cervical vertebra called azat omyrtqa, which was touched by the knife during slaughter.

\section{Bones and viscera as sacred elements of the anatomical code}

Kazakh people like nomads lived in a constant close contact with horses and sheep, which were as a means of transportation, food, clothing, and other household items for them. The Kazakhs' anatomical views, like those of many peoples, have been formed since ancient times when observing animals. G.I. Kabakova, who was the researcher of naive and anatomical concepts, wrote about this tendency: “... As ethnographers drew their attention to an extremely limited knowledge in the anatomy, it is to be surmised that the animal viscera names were referred to the human organ names" (Kabakova 2015, p. 133).

In addition to the skeleton, visceras take a large place in the anatomical linguocultural code, "including brain, heart, lungs, liver, kidney, stomach, intestines, spleen and some genitures" (Podgornaya 2016, pp. 106-107). They have a peculiar hierarchy and culture-bound distinctness in the anatomical code of different peoples. The metonymization and metaphorization mechanisms allowed them to conceptualize visceras cognitively as well as to verbalize their relationship with mental phenomena and entities. This is reflected in the lexical meaning, etymology, associative and connotative links of words and idioms, meaning these organs.

\subsection{Jauyryn}

Let us examine such an important concept for the anatomical code of Kazakh people as jauyryn (lit. "shoulder blade, shoulder bone, humerus") (Bektayev 1995, p. 190). As for a person, this concept includes the connotative meaning of health and male strength, due to functioning of linguistic units in the Kazakh language:

jauyryndy (lit. "shoulder blade") in the meaning of "broad-shouldered" (Bektayev 1995, p. 190);

jauyryndy erkek in the meaning of "a broad-shouldered man" (Bektayev 1995, p. 190);

jauyryny qaqpaqtaı jigit (lit. "a boy with shoulder blades like a lid") in the meaning of " a broad-shouldered boy” (https://sozdik.kz).

I. K. Kenesbayev in his phraseological dictionary gives the proverb "Jauyryny úlken qaqpaqtal, aıdary úlken toqpaqtaı", which describes the body strength and power of a warrior (batyr), glorified in songs and legends (Kenesbayev 2007, p. 109).

A strong fighter, who has always won in such Kazakh kind of sport as qazaqsha qúres, is called jauyryny jerge tımegen baluan (lit. "never touched the ground with his shoulder blades"), whereas a defeated fighter is spoken of as jaýyrynyn jerge tıgizý (lit. "to touch the ground with shoulder blades") in the meaning of "to stack an opponent on his shoulders" (Bektayev 1995, p. 190). In these idioms, the idiomatic meaning is based on the jaýyryn denotative meaning, as well as in the expression jauyrynmen tik turu ("to do a neck-and-shoulder stand"). 
The name koydyk zhauyryny (lit. "a mutton shoulder"), which, in addition to its direct meaning, has a culturally-conditioned ritual one, reflects a lot better the anatomical concept sacredness in Kazakh culture. This cultural meaning goes back to the Old Turkic traditions of shamanism, in which a mutton shoulder has been a fortune-telling bone, i.e. the main natural object used in magic and divination rituals (https://sozdik.kz). Kazakh soothsayers, who did scapulimancy, i.e. divination with the use of a mutton shoulder (jaýyryn), were called jaýyrynshy. Scapulimancy was practiced not only by the Turks, Tibetans, North American Indians, but the ancient Greeks as well. The well-known cultural and folklore specialist Edige Tursunov already in the 1970s pointed out the remarkable similarity of some Kazakh epic's episodes with the Homer's work. Chingis Valikhanov was the first to mention the role of jauyrynshy in the life of Kazakhs. Figure 1 shows a mutton shoulder used as a soothsaying bone.

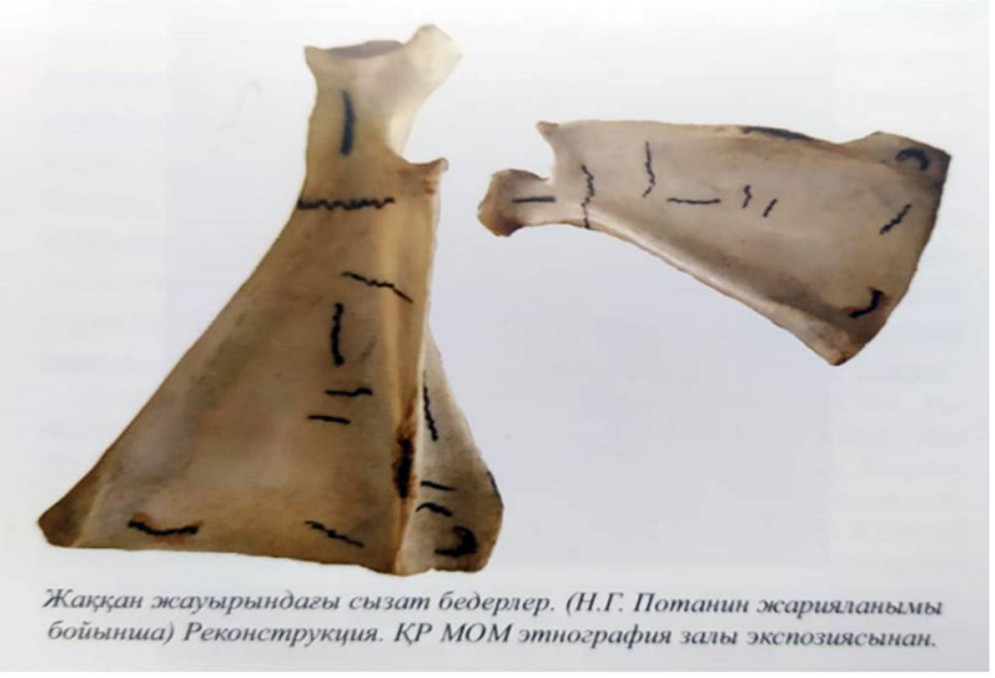

Fig.1. Cracked soothsaying mutton shoulder burnt in fire (Kazakh State Heritage Museum).

Kazakh jauyrynshy "divined with the use of a mutton shoulder. To do this, "they first boil meat and then eat it. But when eating, they should not touch the bone with their teeth. There should be no iron around when throwing the bone into a fire...”. Iron had magic power in the minds of Kazakh people, therefore it could prevent from the divination veracity. This mutton shoulder was heated on fire, resulting in various images cracks, according to which the future was foretold: for example, what kind of winter will be, where a fugitive is, how far the enemies are, will there jute be, etc. The luck depended on the diviner's experience. The experienced diviners were those who could foretell the war events by the unburned mutton shoulder..." (Tokhtabayeva, p. 92).

The mutton shoulder had a magic of connecting jaýyrynshy with ancestral spirits, i.e. aruaqtar. For this very reason it was both as a protection and a talisman, i.e. tumar for home or cattle. "The burnt mutton shoulder divination was an important part of military magic, as well as military ritualism. In the past, each military group had its own jauyrynshy. He had to predict the favourite time of attack, which area the enemies are in, their route of advance, which place an ambush or battle should be laid" (see https://express-k.kz to learn more). Jauyrynshy's divinations were usually foretold in verse.

The five-volume scientific and ethnographic encyclopedia "Qazaqtyń etnografinalyq kategornalar, ugymdar men ataularynyn dástúrli júlesi” (2011-2014) says that the lake Zhasybai in Bayanaul is named after the famous batyr (Kazakh warrior) and jauyrynshy of the Ablaykhan era, who lost in a duel, and was deceived by the Djungarian jauyrynshy. E.D. Tursunov in his work "The 
origins of the Turkic folklore". Korkyt (2001) interprets this event in a rather different way: batyr Jasybaı ordered his military group's jauyrynshy to guess whether the Kalmyks would counterattack, while lying down on a huge boulder. And soothsayers (jauyrynshy), in their turn, started divining, while holding a mutton shoulder:

There is a batyr on the top of a boulder,

Thoughtlessly lying down

There is a sworn enemy in the north side,

Shot, aiming at him

And at that very moment an enemy arrow stuck into batyr Jasybai's forehead.

Shamans, or baqsy were able to predict the future of a born child with the help of a mutton shoulder. The mutton shoulder's longitudinal cracks meant the child's happy and prosperous future, whereas cross-sectional ones - obstacles in his path. The next stage of divination was throwing the mutton shoulder over the shoulder. If it fell with a crest up, then the child would have a good innings, whereas a crest down shoulder meant the child's illness and early death. The final divination stage was the bone cutting. It was forbidden to just throw it away, because any person, finding it, could put the whammy on a child or subjugate his will.

The admonitory expression has a culturally conditioned sacred meaning, i.e. qonaqqa jauyryn tartpaıdy (lit. "guests are not served a mutton shoulder") (Bektayev, p. 190). This custom is related to a sacred intended purpose of the mutton shoulder. Therefore, the shoulder bone was usually served to baqsy, i.e. diviners.

The animals' shoulder blade divination ritual goes back centuries and, first of all, is associated with a cult of domestic animals, which arose in nomadic livelihoods. The wide flat shoulder blade was also used in nomads' daily life as a scoop and a scraper, while the horse and cow shoulder blades served as a copybook when teaching writing.

\section{2. Ókpe}

Another internal organ as a concept of the Kazakh anatomical linguocultural code we are going to analyze is ókpe ("lungs"). Өкne have an extremely specific feature in the Kazakhs' linguistic consciousness from emotional viewpoint: they have particularly negative emotions - resentment, grief, dissatisfaction, reproach, reproof. Numerous idioms with negative and evaluative connotations exemplify this:

$$
\begin{aligned}
& \text { ókpe saqtaý - to bear resentment; } \\
& \text { ókpe aıtý - to express resentment; } \\
& \text { ókpe artý - to be aggrieved; } \\
& \text { ókpe tarqatý - to stop getting offended; } \\
& \text { ókpe-renish - reproaches; } \\
& \text { ókpeli pishin -to look offended; } \\
& \text { ókpeli saryn - a wounded tone (https://sozdik.kz). }
\end{aligned}
$$


"It is no coincidence that in the Kazakh language verbs with the meaning okpeletu (offend) and okpeleu (take offense) are formed from a noun okpe (lungs)" (Temirgazina, Nikolaenko et al. 2020, p.11). Such meaning of expression as "ókpesi qara qazandaı boly" - "take a strong offense" (lit. he has a black cauldron size grievance) (Kozhakhmetova, Zhaisakova, etc., p.148) reflects the archetypical opposition "white" - "black", where "black" describes negative values, phenomena, realias, and emotions, in this particular case. The phraseological unit ökpe aityp qysu - "to oppress somebody with reproaches (lit. "to press somebody by expressing resentment or reproaches") expresses the intense verbalization of resentment by using the word ökpe (Kenesbayev, 2007). The expression without ökpe (lit. lungs are as hard as iron) has two meanings: 1) cruel; heartless (a man); 2) enduring; strong (about the horse).

As we see, an unambiguously negative connotation in ökpe word meanings and phraseological units with this component prevails in the Kazakh language. Perhaps a negative idea of lungs, so widespread among Kazakhs, is related to a healing tradition in the Kazakh culture. According to it, the lungs had sacred magic powers and could "absorb" diseases, negative phenomena and emotions. The ethnographer Sh. Zh. Tokhtabayeva writes about this: "The most popular method of treatment (in particular, warding off the evil eye) is patting the patient's naked body with a freshly cut black sheep lungs. On completing this procedure, the lungs, that "absorbed" the disease, had to be buried in the ground. This tradition is still followed (information by $\mathrm{Z}$. Akhmetzhanova, Almaty)" (Tokhtabayeva, p. 91).

Having analyzed the verbal lexical-phraseological expression of some anatomical concepts, we came to a conclusion that they have a high degree of sacredness, reflected in the connotative meanings of verbal units. The degree of sacredness was identified in accordance with the degree of verbal units' total number, which represented the anatomical meaning, and the number of verbal units that included a culturally conditioned connotation in their semantics, going back to magic traditions, rituals, rites, pagan views of the ancient Turks and Kazakhs. See Table 2.

Table 2. Degree of anatomical concepts sacredness included in the Kazakh cultural code

\begin{tabular}{cccc}
$\begin{array}{c}\text { Anatomical } \\
\text { concept }\end{array}$ & $\begin{array}{c}\text { Verbal units } \\
\text { (total number) }\end{array}$ & $\begin{array}{c}\text { Sacred meaning } \\
\text { units (number) }\end{array}$ & $\begin{array}{l}\text { Concepts } \\
\text { sacredness degree } \\
\text { (in percentage } \\
\text { terms) }\end{array}$ \\
\hline
\end{tabular}

\begin{tabular}{lccc}
\hline on eki müşe & 10 & 7 & $70 \%$ \\
\hline Jauyryn & 10 & 3 & $30 \%$ \\
\hline Ökpe & 13 & 10 & $76,9 \%$ \\
\hline
\end{tabular}

\section{Conclusion}

The language as a secondary semiotic system still preserves the archaic views, mythological thinking, magic rituals and rites. A much slower evolution of language, compared to culture and world knowledge, is, according to scientists, due to an archaic relic worldview, as well as cultural codes, preserved in it. 
We have studied one of the most ancient cultural codes, i.e. anatomical, where certain concepts - body parts, bones, and internal organs serve as the sign units. Having developed the methodology for studying these concepts, based on the secondary semiotic sign analysis, i.e. lexical and phraseological verbal units and their semantics: denotative and connotative, we have defined certain concepts' degree of sacredness.

The concept on eki mushe (twelve parts of the body), being the main concept of the Kazakh anatomical code, is related to a high degree of sacredness - $70 \%$, dating back to the ancient Tengrian cosmogonic views of the Turkic nomads. The anatomical concepts of ökpe (lungs) - $76.9 \%$ and jauyryn (a shoulder blade) - 30\% also have a high degree of sacredness, associated with magic rituals. The study of other anatomical concepts in order to recreate the complete anatomical cultural code of the Kazakh people may become directions for future research.

The human body, knowledge about it, its structure, organs, parts and functions are a really infinite source for understanding and getting to know peoples' spiritual and sacred culture.

\section{References}

Agapova T.V. Culture as a horizon of signs and values // Bulletin of the Chuvash University, \# 3. 2009, pp. $351-356$.

Akopyan V. G. Interaction of cultural codes with natural language code // Volga Pedagogical Bulletin, \# 2 (7). 2015, pp.71-75.

Andersen E. S. Lexical universals of body-part terminology. In: Greenberg, J. H. (Ed.), Universals of Human Language. Stanford University Press, Stanford, 1978. P. 335-368.

Babosov E. Cultural code of the nation: essence and features // Science and innovations, vol. 3, \# 157.2016, pp. 48-50.

Bart R. Selectas. Semiotics. Poetics. Moscow: Progress, 1994. 616 p.

Bashkatova Yu. A. Somatic code of culture as a subject of comparative research // Siberian Journal of Philology. 2014. \# 4. P. 220-228.

Bektayev K.B. A large Kazakh-Russian, Russian-Kazakh dictionary. Almaty, 1995. 697 p.

Body code in Slavic cultures / ed.-in-chief. N.V. Zlydneva. Moscow: Institute of Slavic philology RAS, 2005. $273 \mathrm{p}$.

Borisova I.Z. Comparative analysis of proverbs with "hand", "leg", "head" units // Bulletin of the Udmurt University. Series: History and Philology. 2015. Vol. 25, \# 2.P. 111-119.

Bukina N.V. Cultural code as a language of culture // Bulletin of the Trans-Baikal State University, \# 2. 2008, pp. 69-73.

Cassirer E. Selectas. Knowledge of a person: Introduction to the philosophy of human culture. Moscow: Gardariki, 1998. P. 440-722.

Dmitriuk N.V. Phraseological somaticon as a reflection of archetypes of ethnic group's linguistic consciousness // Questions of psycholinguistics. 2009, \# 10, pp. 30-33.

Dukalskaya I.V. Linguocultural code as a means of communicative competence formation. Almanac of modern science and education. Tambov: Diploma, 2011, \# 4 (47). pp. 128-129.

Eco U. Lacking structure. Introduction to semiology. SPb.: LLP TC “Petropolis”, 1998. 432 p.

Electronic resource. URL: https://express-k.kz/news/nauka expert/ zerkalnaya lopatka-160371 (visiting date: 20.01.2021). 
Electronic resource. URL: https://sozdik.kz (visiting date: 19.01.2021).

Enfield N. J., Majid A., Staden van M. Cross-linguistic categorisation of the body // Language Sciences. 2006. \#28. Pp.137-147

Gudkov D. B. Units of culture codes: the problem of semantics // Language, consciousness, communication: collection of articles. M.: Max Press, 2004. Vol. 26, pp. 39-50.

Gudkov D. B., Kovshova M. L. The body code of Russian culture: dictionary materials. Moscow: Gnosis, 2007.

Kabakova G. I. "Naive anatomy" in the language reflector: alimentary tract // Ethnolinguistics. Onomastics. Etymology. Yekaterinburg: the Ural University Publishing House, 2015. Electronic resource. URL:galina.kabakova@libertysurf.fr (a visiting date 20.01.2021).

Kenesbayev I. K. Qazaq tilinin frazeologialyq sozdigi. Almaty: QazAqparat, 2007.356 p

Kozhakhmetova Kh.K., Zhaisakova R.E., Kozhakhmetova Sh. O. Kazakh-Russian phraseological dictionary. Alma-Ata: Mektep, 1988. 224 p.

Kraska-Szlenk I. Semantic extensions of body part terms: Common patterns and their interpretation // Language Sciences. 2014. \#44. Pp. 15-39. DOI: 10.1016/j.langsci.2014.02.002

Krasnykh V.V. Ethnopsycholinguistics and cultural linguistics. Moscow: Gnosis, 2002.

Liston J. L. The Semantic Structure of Body-Part Terms in Serbo-Croatian: I. The PartWhole Hierarchy. Anthropological Linguistics. 1972. \#14(8). Pp. 323-338.

Lotman Yu.M. Culture and explosion. Moscow: Nauka, 1992.

Lotman Yu.M. Inside the thinking worlds. Man - text - semiosphere - history. Moscow: Languages of Russian culture, 1996. $464 \mathrm{p}$.

Lotman Yu.M. Semiosphere. SPb.: Art - SPb, 2000. 704 p.

Oinotkinova N.R. Somatic code of culture in the proverbs and sayings of the Altaians // Siberian Journal of Philology. 2011. \# 3. Pp. 5-14.

Podgornaya V.V. "Naive anatomy" in the English language worldview. SPb.: Saint Petersburg State University, 2016. 226 p.

Rakhimzhanov K. Kh., Akosheva M.K., Temirgazina Z.K. Metaphoric and metonymic interpretation of the heart in the Kazakh and Tuvan languages: the interaction of language, anatomy and culture // New studies of Tuva. 2020. №4. P. 261-271. DOI: www.doi.org/10.25178/nit.2020.4.18

Savchenko L.V. Functions of cultural somatic code in the formation of phrase system in Russian and Ukrainian languages // Transactions of the Tavria National University named after Vernadsky V.I. Ser. Philology. Social communications. 2014.Vol. 27 (66), \# 2. Pp. 88-92.

Savitskiy V.M. Modeling problem in the phraseological system of language: dis. ... Dr. Philology. Moscow, 1996. $48 \mathrm{p}$.

Savitsky V.M. Lingvocultural codes: to substantiate the concept // Vestnik MGOU. Series: Linguistics. 2016. \# 2. Pp. 55-62.

Stepanova N.I. Cultural codes: semiotic and cultural aspects // Ideas and ideals. Vol. 2, \# 1. 2012. Pp. 130-136.

Temirgazina Z., Akosheva M., Shakaman Y., Shaharman A., Kurmanova Z., Kairova M. Metaphors in Anatomical Terminology // Space and Culture, India. 2019. Vol. 7:1. Pp.143-153.

https://doi.org/10.20896/saci.v7i1.528 
Temirgazina Z., Khamitova G., Orazalinova K. Didactic Features of a Learner's English-Russian Dictionary of Biology Development. Research Journal of Pharmaceutical, Biological and Chemical Sciences. 2016. No 7(2). Pp. 317-326.

Temirgazina Z., Nikolaenko S., Akosheva M., Luczyk M., Khamitova G. "Naive anatomy" in the Kazakh language world picture in comparison with English and Russian //XLinguae, Vol. 13, Issue 2. 2020. Pp. 3-16. DOI: 10.18355/XL.2020.13.02.01

Terrill A. Body part terms in Lavukaleve, a Papuan language of the Solomon Islands. Language Sciences. 2006. \#28. Pp. 304-322.

Tokhtabayeva Sh. Zh. Etiquette norms of Kazakhs. Part II. Family and society. La Grâce, 2017. 170 p.

Traditional system of ethnographic categories of concepts and names among the Kazakhs. In 5 volumes. Ed. Nursan Alimbay. Almaty: DPS, 2011-2014.

Tursunov E. D. Origins of the Turkic folklore. Korkyt. Almaty: Dyke-Press, 2001. 168 p.

Xin-i Guo. Somatic code in Russian and Chinese phraseology // Bodily code in Slavic cultures. M.: Institute of Slavic philology RAS, 2005. Pp. 30-40.

Zavalishina K. G. Sphere of concepts "a bodily man" in the Russian, German and English folk songs: dis. of Cand. Sc. Philology. Kursk, 2005. 243 p. 